value $<0,05$ and $r=0,486, p$ value $<0,01$ respectively), depressed bronchial resistance SGaw $(r=0,773$, p value $<0,01)$ and increased $R V(r=-0,736$, $p$ value $<0,01$ ), which determined BO severity.

Conclusions: More than half of patients with RA have BO predominantly in terminal bronchioles. Accepting significant decrease of Clara cell protein $\mathrm{CC} 16$ in patients with RA having $\mathrm{BO}$ we suppose pathogenic relationship between functional depression of Clara cell anti-inflammatory activity and BO in this category of patients.

References:

[1] Park HY. Club cell protein 16 and disease progression in chronic obstructive pulmonary disease (2013).

Disclosure of Interest: None declared

DOI: 10.1136/annrheumdis-2017-eular.4585

\section{SAT0112 PREVALENCE AND INCIDENCE OVER 3 YEARS OF DIFFERENT COMORBIDITIES IN RHEUMATOID ARTHRITIS (RA): A 3 YEAR LONGITUDINAL STUDY IN 769 ESTABLISHED RA PATIENTS}

L. Gossec, M. Soubrier, F. Foissac, F. Fayet, N. Balandraud, T. Bardin, C. Beauvais, G. Chales, I. Chary-Valckenaere, E. Dernis, L. Euller-Ziegler, R.-M. Flipo, M. Gilson, T. Marhadour, X. Mariette, G. Mouterde, S. Pouplin, P. Richette, A. Ruyssen-Witrand, T. Schaeverbeke, C. Sordet, M. Dougados. COMEDRA working group, Paris, France

Background: Comorbidities including cardiovascular (CV) risk, cancer and osteoporosis are frequent in RA.[1]

Objectives: To quantify at baseline and 3 years later, the prevalence (at baseline) and incidence (over 3 years) of some selected comorbidities.

Methods: This was an open long term ( 3 years) extension of the COMEDRA 6-month randomized controlled trial in which patients with definite, stable RA were visiting a nurse for comorbidity counselling.[2] Comorbidity status was assessed through face-to-face interviews and nurses provided advice on screening and management, at baseline and 3 years later. The frequency of comorbidities was assessed at both timepoints and incidence of new cases was assessed as overall $\%$ of patients and as relative increase in the given comorbidity.

Results: Of the 970 recruited patients, $776(80 \%)$ were followed up at 2-4 years $(15,1.5 \%$, had died) and $769(79 \%)$ had available data for comorbidities at both timepoints: at baseline, mean $( \pm S D)$ age $58( \pm 11)$ years, mean disease duration $14( \pm 10)$ years; $614(80 \%)$ were women and $538(70 \%)$ were receiving a biologic with a mean DAS28 of $3.1 \pm 1.3$.

At baseline, the most frequent comorbidities were history of fracture $(31.9 \%)$ and high blood pressure $(30.9 \%)$ and at 3 years the comorbidity which had most increased (i.e., incidence) in this population aged around 60 years, was high blood pressure (4\%) whereas smoking had decreased (Table).

Table: frequency of comorbidities at baseline and 3 years later

\begin{tabular}{|l|c|c|c|}
\hline Comorbidity & $\begin{array}{c}\text { COMEDRA study } \\
\text { baseline (month 0 for } \\
\text { group I and month 6 } \\
\text { for group II) }\end{array}$ & $\begin{array}{l}\text { Follow-up at } \\
3 \text { years }\end{array}$ & $\begin{array}{l}\text { Absolute increase, \% of } \\
\begin{array}{l}769 \text { patients (relative } \\
\text { increase, \% of baseline } \\
\text { prevalence) }\end{array}\end{array}$ \\
\hline $\begin{array}{l}\text { Myocardial } \\
\text { infarct }\end{array}$ & $13(1.7)$ & $18(2.3)$ & $0.6(38.4)$ \\
\hline Angina & $9(1.2)$ & $17(2.2)$ & $1.0(88.9)$ \\
\hline Stroke & $16(2.1)$ & $29(3.8)$ & $1.7(81.2)$ \\
\hline $\begin{array}{l}\text { Obliterating } \\
\text { arteriopathy }\end{array}$ & $8(1.0)$ & $14(1.8)$ & $0.8(75.0)$ \\
\hline Diabetes & $39(5.1)$ & $50(6.5)$ & $1.4(28.2)$ \\
\hline $\begin{array}{l}\text { High Blood } \\
\text { Pressure }\end{array}$ & $238(30.9)$ & $270(35.1)$ & $4.2(13.4)$ \\
\hline Hyperlipidemia & $149(19.4)$ & $170(22.1)$ & $2.7(14.1)$ \\
\hline $\begin{array}{l}\text { Obesity } \\
\text { BMl>-30) }\end{array}$ & $114(14.8)$ & $124(16.1)$ & $1.3(8.8)$ \\
\hline Smoking & $120(15.6)$ & $104(13.5)$ & $-2.1(-13.3)$ \\
\hline Colon cancer & $2(0.3)$ & $2(0.3)$ & $0(0)$ \\
\hline Breast cancer & $23(3.0)$ & $27(3.5)$ & $0.5(17.4)$ \\
\hline Lung cancer & $1(0.1)$ & $2(0.3)$ & $0.2(100.0)$ \\
\hline Prostate cancer & $3(0.4)$ & $4(0.5)$ & $0.1(33.3)$ \\
\hline Uterus cancer & $7(0.9)$ & $7(0.9)$ & $0(0)$ \\
\hline $\begin{array}{l}\text { Skin cancer (all } \\
\text { types) }\end{array}$ & $26(3.4)$ & $36(4.7)$ & $1.3(27.8)$ \\
\hline Lymphoma & $2(0.3)$ & $3(0.4)$ & $0.1(50.0)$ \\
\hline $\begin{array}{l}\text { History } \\
\text { fracture }\end{array}$ & $245(31.9)$ & $256(33.3)$ & $1.4(4.5)$ \\
\hline
\end{tabular}

Conclusions: Comorbidities are frequent in RA though screening does not always address the most frequent or severe comorbidities. Efforts must be pursued to improve comorbidity screening and prevention.

References:

[1] Ref 1. Baillet A, Gossec L et al. Ann Rheum Dis. 2016;75(6):965-73.

[2] Ref 2. Dougados M, Soubrier M, et al. Ann Rheum Dis. 2015;74(9):1725-33.

Acknowledgements: grant from Roche France and from the French National Research Program (PHRC AOM 12072).

Disclosure of Interest: None declared

DOI: 10.1136/annrheumdis-2017-eular.2978

\section{SAT0113 OBESITY AND METABOLIC SYNDROME INFLUENCE ON N-TERMINAL PRO-BRAIN NATRIURETIC PEPTIDE LEVELS IN RHEUMATOID ARTHRITIS PATIENTS}

L. Kondratyeva, T. Popkova, I. Kirillova, D. Novikova, A. Novikov, E. Alexandrova E. Nasonov. V.A. Nasonova Research Institute of Rheumatology, Moscow, Russian Federation

Background: N-terminal pro-brain natriuretic peptide (NT-proBNP) is a recognized myocardial injure marker, a known predictor of heart failure and cardiovascular death. Rheumatoid arthritis (RA) patients (pts) were shown to have higher than in general population NT-proBNP concentrations, positively correlating with IL-6 levels. Adipose tissue is considered be one of the sources of this pro-inflammatory cytokine. But on the other hand, metabolic syndrome (MS) and obesity, which also occur in RA pts, are usually associated with lower NT-proBNP levels in general population.

Objectives: To find out whether overweight/obesity or MS may modify NT-proBNP levels in RA pts.

Methods: A total of 68 early RA pts $(72 \%$ females, $28 \%$ males) was enrolled in the study. Mean disease duration was $6[4 ; 8]$ months, and RA activity using DAS28 calculator was $5,6[5,1 ; 6,4]$ scores. The majority of pts had positive RF $(87 \%)$ and ACPA (88\%). All pts were glucocorticoids and disease-modifying antirheumatic drugs - naïve prior to inclusion. The overweight/obesity was determined by WHO criteria in patients with body mass index (BMI) $\geq 25$ $\mathrm{kg} / \mathrm{m}^{2}$. National Cholesterol Education Program/Adult Treatment Panel III criteria were used to confirm MS. Serum levels of NT-proBNP $(\mathrm{pg} / \mathrm{mL})$ were measured using electrochemiluminescence test Elecsys proBNP II (Roche Diagnostics, Switzerland). NT-proBNP levels $>125,0 \mathrm{pg} / \mathrm{mL}$ were considered as elevated.

Results: Overweight and obesity were established in $54,4 \%$ RA pts. Overweight/obese RA pts were older than pts with normal BMI (57 [53;61] years vs $48[34 ; 61]$ years, $p=0,02)$, had higher DAS28 scores $(5,85[5,20 ; 6,57]$ vs $5,28[4,76 ; 5,69], p<0,01)$, higher CRP $(38,8[14,3 ; 47,9] \mathrm{mg} / \mathrm{L}$ vs $12,8[2,2 ; 28,8]$ $\mathrm{mg} / \mathrm{L}, p<0,01)$. Elevated NT-proBNP concentrations were found in $62,2 \%$ overweight/obese pts vs $29,0 \%$ pts with normal weight $(p<0,01)$, median NT-proBNP concentrations were $153,4[87,3 ; 236,9] \mathrm{pg} / \mathrm{mL}$ vs $75,2[40,2 ; 147,4] \mathrm{pg} / \mathrm{mL}$, respectively $(p=0,02)$. MS was established in $62,2 \%$ pts with $\mathrm{BMI} \geq 25 \mathrm{~kg} / \mathrm{m}^{2}$ and in $25,8 \%$ pts with $\mathrm{BMl}<25 \mathrm{~kg} / \mathrm{m}^{2} \quad(p<0,01)$. Median NT-proBNP concentrations did not vary significantly in pts with and without MS, whether they were overweight/obese $(p=0,75)$, or had normal $\mathrm{BMI}(p=0,27)$. Although higher rates of elevated NT-proBNP concentrations were documented in pts with MS $(61,3 \%$ vs $35,1 \%, p=0,03)$. NT-proBNP levels positively correlated with waist circumference $(r=0,33, p<0,01)$, ESR $(r=0,25, p=0,04)$, and CRP $(r=0,3, p=0,01)$.

Conclusions: Overweight and obesity in RA pts were associated with increased NT-proBNP levels. Abdominal obesity was identified as the only MS component, influencing NT-proBNP levels, presumably via up-regulation of the inflammatory process.

Disclosure of Interest: None declared

DOI: 10.1136/annrheumdis-2017-eular.3731

\section{SAT0114 POOR CARDIOVASCULAR RISK MANAGEMENT IN RHEUMATOID ARTHRITIS PATIENTS DESPITE AN EXPLICIT CARDIOVASCULAR RISK MANAGEMENT PROGRAM}

M. Heslinga ${ }^{1}$, I. van den Oever ${ }^{1}$, E. Griep ${ }^{2}$, H. Griep-Wentink ${ }^{2}$, Y. Smulders ${ }^{3}$, W. Lems ${ }^{1,4}$, M. Boers ${ }^{1,4}$, A. Voskuyl $^{4}$, M. Peters ${ }^{3}$, D. van Schaardenburg ${ }^{1}$, M. Nurmohamed ${ }^{1,4} .{ }^{1}$ Amsterdam Rheumatology and immunology Center $/$ Reade, Amsterdam; ${ }^{2}$ Antonius Hospital Zuidwest Friesland, Sneek; ${ }^{3} \mathrm{VU}$ University Medical Center; ${ }^{4}$ Amsterdam Rheumatology and immunology Center I VU University Medical Center, Amsterdam, Netherlands

Background: In 2011, we started a cardiovascular (CV) risk management program for rheumatoid arthritis (RA) patients visiting Reade in the Netherlands. We previously reported the presence of under treatment of hypercholesterolemia and hypertension [1].

Objectives: To assess the effectiveness of our $\mathrm{CV}$ risk management program after one year.

Methods: CV risk screening was performed at baseline and we informed the general practitioner (GP) about the results, including advices regarding the initiation of cardio preventive drugs. In high risk patients, antihypertensives were recommended when systolic blood pressure $>140 \mathrm{~mm} / \mathrm{Hg}$ and statins were recommended when low-density lipoprotein $>2.5 \mathrm{mmol} / \mathrm{l}$. The decision to start preventive medication was left to the GP. CV risk screening was repeated after one year. Patients completed a questionnaire about the actions that were taken following the results of the initial screening.

Results: Of the 266 patients $202(76 \%)$ were female, the mean age was $58 \pm 11$ years. After one year, 88 out of 134 patients who received inadequate or no treatment at baseline were still untreated or undertreated. Of the $188(71 \%)$ patients who were at high $\mathrm{CV}$ risk and who did have an indication to start therapy, only $7.5 \%$ was contacted by their GP and another $6.8 \%$ arranged an appointment themselves. While the 10-year CV risk did not decrease in the group as a whole, a risk reduction was found in the patients that started medication. Remarkably, $42 \%$ of patients reported lifestyle changes, including more exercise $(20 \%)$, diet adaption (16\%) and weight loss (9\%).

Conclusions: It is striking that one year after the introduction of our CV risk 